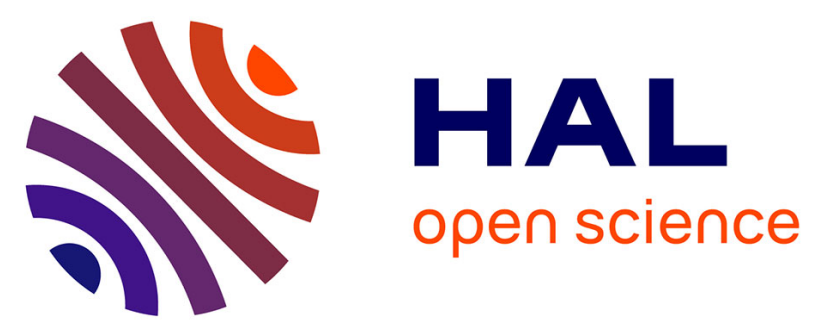

\title{
Influence of multilayer loading of dissimilar particulate solids into a batch mixer on mixing kinetics and capacity
}

Vadim E. Mizonov, Ivan Balagurov, Henri Berthiaux, Cendrine Gatumel

\section{To cite this version:}

Vadim E. Mizonov, Ivan Balagurov, Henri Berthiaux, Cendrine Gatumel. Influence of multilayer loading of dissimilar particulate solids into a batch mixer on mixing kinetics and capacity. Izvestiya Vysshikh Uchebnykh Zavedeniy Seriya "Khimiya I Khimicheskaya Tekhnologiya", 2016, 59 (10), pp.5460. 10.6060/tcct.20165910.5373 . hal-03201919

\section{HAL Id: hal-03201919 https://imt-mines-albi.hal.science/hal-03201919}

Submitted on 20 Apr 2021

HAL is a multi-disciplinary open access archive for the deposit and dissemination of scientific research documents, whether they are published or not. The documents may come from teaching and research institutions in France or abroad, or from public or private research centers.
L'archive ouverte pluridisciplinaire HAL, est destinée au dépôt et à la diffusion de documents scientifiques de niveau recherche, publiés ou non, émanant des établissements d'enseignement et de recherche français ou étrangers, des laboratoires publics ou privés. 
В.Е. Мизонов, И.А. Балагуров, Н. Berthiaux, С. Gatumel

Вадим Евгеньевич Мизонов $(\boldsymbol{\nabla})$, Иван Александрович Балагуров

Кафедра прикладной математики, Ивановский государственный энергетический университет,

Рабфаковская 34, 153003 Иваново, Россия

E-mail: mizonov46@mail.ru (凶)

Henri Berthiaux ( $\square)$, Cendrine Gatume

Centre RAPSODEE, UMR CNRS 5302, Ecole des Mines d'Albi-Carmaux, Albi, 81013, France

E-mail: berthiau@enstimac.fr $(\otimes)$

\title{
ВЛИЯНИЕ МНОГОСЛОЙНОЙ ЗАГРУЗКИ РАЗНОРОДНЫХ ЗЕРНИСТЫХ МАТЕРИАЛОВ В СМЕСИТЕЛЬ ПЕРИОДИЧЕСКОГО ДЕЙСТВИЯ НА КИНЕТИКУ И ПРОИЗВОДИТЕЛЬНОСТЬ СМЕШИВАНИЯ
}

\begin{abstract}
Целью настоящей работы является демонстрация нескольких оптимизационных задач периодического смешивания склонных к сегрегации сыпучих материалов, которые могут быть поставлены и решены на основе моделей, основанных на теории цепей Маркова. Для того, чтобы повысить адекватность моделирования и исключить некоторые физические противоречия, которые возникают при использовании линейных моделей, предложена нелинейная Марковская модель перемешивания сегрегирующих компонентов. Исследовано влияние начального распределения компонентов после их загрузки в смеситель на оптимальное время перемешивания и качество смеси. Показано, что однократная загрузка компонентов как два вертикальных слоя значительно хуже, чем их многослойная как несколько сэндвичей. Принимая во внимание то, что полное время обработки смеси включает время собственно перемешивания и время загрузки, которое пропорционально числу сэндвичей, было определено оптимальное число сэндвичей. Приведены экспериментальные свидетельства того, что многослойная загрузка может быть реализована в практике смешивания.
\end{abstract}

Ключевые слова: сыпучий материал, смешивание, сегрегация, многослойная загрузка, цепь Маркова, оптимизация, качество смеси, время смешивания 


\section{V.E. Mizonov, I.A. Balagurov, H. Berthiaux, C. Gatumel}

Vadim E. Mizonov ( $\varangle$ ), Ivan A. Balagurov

Department of Applied Mathematics, Ivanovo State Power Engineering University, Rabfakovskaya 34,

Ivanovo, 153003, Russia

E-mail: mizonov46@mail.ru (凶)

Henri Berthiaux $(\varangle)$, Cendrine Gatume

Centre RAPSODEE, UMR CNRS 5302, Ecole des Mines d'Albi-Carmaux, Albi, 81013, France

E-mail: berthiau@enstimac.fr $(\varangle)$

\section{INFLUENCE OF MULTILAYER LOADING OF DISSIMILAR PARTICULATE SOLIDS INTO A BATCH MIXER ON MIXING KINETICS AND CAPACITY}

The objective of the study is to show several optimization problems in batch mixing of segregating particulate solids that can be set up and solved using the Markov chain models. A non-linear Markov chain model for mixing of segregating components is proposed to improve the model adequacy and to exclude some physical contradictions that arise in linear models. The influence of initial components distribution after their loading into a mixer on the optimum mixing time and mixture quality is examined. It is shown that the one-time loading of the components as two vertical layers is much worse than the multilayer loading of them as several sandwiches. The optimum number of layers, or sandwiches, is found taking into account that the total time of mixture treatment includes the time of mixing itself and the loading time that is proportional to the number of sandwiches. Some experimental evidences that the multilayer loading can be realized in the practice of mixing are also presented.

Key words: particulate solids, mixing, segregation, multilayer loading, Markov chain, optimization, mixing quality, mixing time

\section{INTRODUCTION}

Mixing of powders and granular materials is of central importance for the quality and performance of a wide range of products. It is emphasized in $[1,2]$ that the design and operation of the mixing process are very difficult, being largely based on judgments rather than science. The next stage of development is to build on the emerging knowledge and methods so that the basics for such design can be laid down. Then this design can become predictable with operation giving effective control of performance. One of the key problems in mixing of dissimilar granular materials is their segregation into each other. The segregation occurs due to differences in physical properties of the components, such as particle size, density, shape, etc. Action of gravity that is always present in mixing is different on different sorts of particles and also leads to their segregation. At no segregation the achievement of homogeneous mixture is the problem of mixing time alone. Very often it is virtually impos- sible to achieve the state of homogeneous mixture if segregation occurs. First, the homogeneity of a mixture increases, then passes its maximum and decreases again. There are a lot of studies, mostly experimental, on influence of the segregation effect on mixture quality (for instance, the papers [3-5] and others). However, the effect of segregation on mixing kinetics is studied much less.

Modeling the process mathematically helps to understand it better and to search for the ways how it can be improved. However, it is important to choose an appropriate mathematical tool that allows to set up the optimization problems clear and to get optimal solutions that are not too far from possible practical realization.

According to the authors' viewpoint such tool is the theory of Markov chains, which is rather native to the process of mixing because both are related to the evolution of the state of a stochastic system. The basic idea of the Markov chain approach consists in 
separating the operating volume of the mixer into small but finite zones (cells) and then observing the evolution of the key component concentration in the zones at discrete moments of time after a small but finite time step between them. Application of the approach to describe the state of mixture after passing a static mixer was published in [6]. However, in this work, the approach missed the evolution of process parameters and did not present the physical features of the mixing zone. In further works by the authors [7, 8], the model, in which transitions only to the neighboring cells were allowed, was developed.

The general strategy of application of the theory of Markov chains to model different processes in powder technology was described in our previous papers [9-11]. However, these and all other works use the theory namely to describe the process and practically never use the theory to optimize it.

Presented below, the results of the theory application to modeling the kinetic of the binary mixture formation are mainly based on the approach described in [12] where it was used to model and optimize the mixing of two dissimilar components of particulate solids. It was mentioned in this work that the structured loading of dissimilar components into a batch mixer can give a considerable gain in comparison to the common loading of them as two separated layers: one component to the bottom of a mixer, and another (segregating downward) one to its top. The detailed study of the approach to improve mixing quality and capacity is the objective of the paper.

\section{THEORY}

Suppose that a batch mixing zone is presented as a one-dimensional array of m perfectly mixed cells. The key segregating component distribution over the cells can be described by the column state vector $\mathbf{S}=$ $\left\{S_{j}\right\}$ of the size $m \times 1$. As far as the objective of the study is a binary mixture of particulate solids, the downward segregation of a key component always goes together with the upward segregation of a basic component in accordance with the continuity equation. In each cell, the relative content of the basic component is equal to one minus the relative content of the key component. Thus, in order to estimate the mixture quality, it is enough to know how the key component is distributed over the operating volume of a mixer. Namely this distribution and its characteristics will be the objective function of optimization.

Also suppose that we observe the state of the process at discrete moments of time $t_{k}=(k-1) \Delta t$ where $\Delta \mathrm{t}$ is the transition duration, and $\mathrm{k}$ is the transition number that can be interpreted as the discrete analogue of time. In this case, the evolution of the key component state (i.e., mixing kinetics) can be described by the recurrent matrix equation:

$$
\mathbf{S}^{\mathbf{k}+1}=\mathbf{P S}^{\mathbf{k}} \text {, }
$$

where $\mathbf{P}$ is the matrix of transition probabilities that distributes $S_{j}$ over the cells at each time step, or transition. The j-th column of it belongs to the $j$-th cell and contains the transition probabilities to go to the neighboring cells and to stay within this cell. These probabilities have the symmetrical part $d$ that is related to the pure quasi-diffusion, which always leads to flattening of the component distribution, and the nonsymmetrical part $\mathrm{v}$ that is related to segregation, which leads to non-homogeneity. The values of $d$ and $\mathrm{v}$ can be calculated as: $\mathrm{d}=\mathrm{D} \Delta \mathrm{t} / \Delta \mathrm{x}^{2}, \mathrm{v}=\mathrm{V} \Delta \mathrm{t} / \Delta \mathrm{x}$ where $\mathrm{D}$ is the dispersion coefficient, $\mathrm{V}$ is the rate of segregation, $\Delta \mathrm{x}$ is the cell height. Thus, the matrix $\mathbf{P}$ is a tri-diagonal matrix. In the linear models, the matrix is kept constant from one transition to another. However, it is a very rough assumption to keep the value of $v$ constsnt. It can lead not only to quantitative errors but also to qualitative contradictions. Indeed, a segregating component cannot segregate inside itself, and, if the (j+1)-th cell is filled with it fully (contains $S_{\max }$ of it), the value of $v$ should be equal to zero. On the contrary, if the $(j+1)$-th cell does not contain it at all, the value of $\mathrm{v}$ should be maximal. It is natural to introduce the assumption that the dependence between $v$ and $S_{j+1}{ }^{k}$ is linear:

$$
v_{j}^{k}=v_{0}\left(1-\frac{S_{j+1}^{k}}{S_{\max }}\right),
$$

where $\mathrm{v}_{0}$ is the rate of segregation into the pure basic component and $S_{\max }$ can be supposed to be equal to 1 .

Thus, the model becomes non-linear because the matrix $\mathbf{P}$ depends on the current state vector $\mathbf{S}^{\mathbf{k}}$ and varies at each time transition. Under this assumption the entries of the matrix $\mathrm{P}$ can be calculated as:

$$
\begin{aligned}
& P_{j, j+1}^{k}=v_{0}\left(1-S_{j+1}^{k}\right)+d, j=1, \ldots, m-1 \\
& P_{j+1, j}^{k}=d, j=1, \ldots, m-1 \\
& P_{j, j}=1-\sum_{i=1, i \neq j}^{m} P_{i, j}^{k}, i=1, \ldots, m .
\end{aligned}
$$

The technological objective of mixing of solids is to obtain the mixture, in which a key component is distributed over the mixture volume as homogeneously as possible, or meets technological requirements on the mixture non-homogeneity. If the nonhomogeneity is characterized by the standard deviation of a key component distribution $\sigma$, this condition can be formulated as $\sigma \rightarrow \sigma_{\min }$, or $\sigma \leq \sigma_{\mathrm{c}}$. If the parameters of the mixture agitation in a mixer are given (i.e., the values of $d$ and $v_{0}$ are defined), the only way to optimize the process is to find the optimal mixing 
time, at which $\sigma=\sigma_{\min }$. Under these conditions, there is no ways to influence on the matrix $\mathbf{P}$ but it is possible to influence on the initial state vector $\mathbf{S}^{\mathbf{0}}$ that is being formed during the loading of components into a mixer.

The common way to begin the mixing process is to place a segregating key component to the top of a mixing zone above a basic component and to run the mixer, i.e., to introduce agitation of the mixture by mechanical action (vibration, blades, etc.). However, such one-time loading does not allow reaching the homogeneous mixture, and the minimum standard deviation very often is higher than it is necessary due to technological requirements. Formally, there exists the theoretical way to reach the homogeneous mixture of segregating components. It is necessary to take from the components particle by particle and to put them into the mixing volume in the proper order. However, the capacity of such mixing process is close to zero. A compromise settlement is to load the com- ponents into the mixing volume layer by layer like sandwiches, in which the number layers of the components keep the same proportion as in the total mixture. In this case, the process of loading becomes a sort of pre-mixing, and only short time post-mixing is required after that in order to reach the necessary homogeneity.

In order to estimate the efficiency of multilayer loading the numerical experiments were carried out with the model described above. The results of them are shown in Fig.1. The number of cells was taken equal to 48 , i.e., one cell was the scale of the probe to measure the content of the key component, which total content in the mixture was 1:5. The calculations were done for $\mathrm{v}_{0}=0.2$ and $\mathrm{d}=0.3$. The initial distributions of the key component are shown at the top of the graph, the mixing kinetics - in the middle, and the distributions of the key component after mixing during the optimal mixing time are shown at the bottom of it.
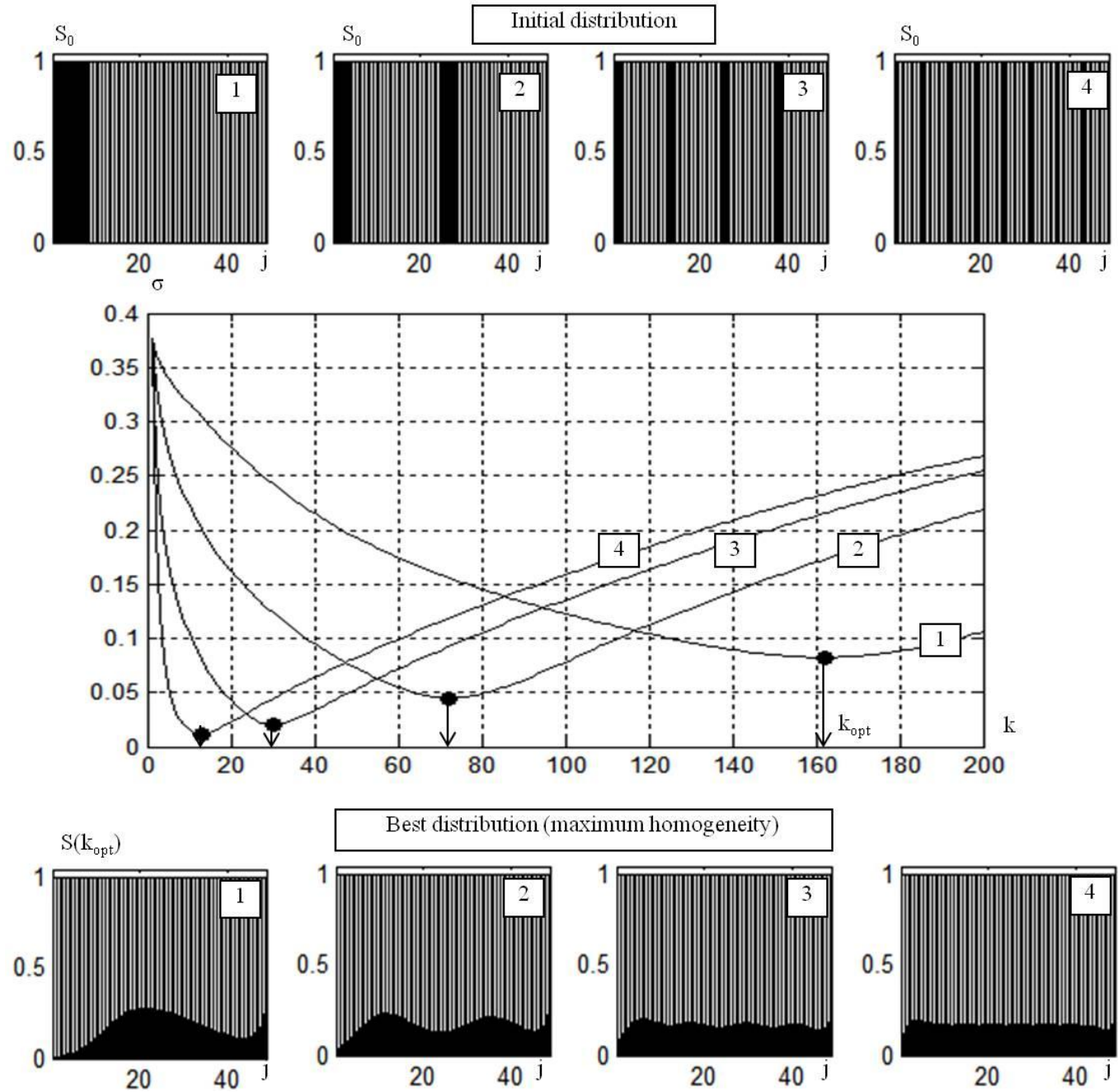

Fig.1. Influence of initial distribution on mixing kinetics and component distribution at maximum homogeneity of the mixture Рис. 1. Влияние начального рапределения на кинетику смешения и распределение компонентов при максимальной однородности смеси 
The case 1 is related to the one time loading. The best mixing quality is being reached after 162 time transitions when $\sigma_{\min }=0.0824$. The cases 2,3 and 4 are related to the multilayer loading as 2, 4 and 8 sandwiches respectively. It can be seen that the growth of the sandwiches number leads to the considerable decrease of $\sigma_{\min }$ (the increase of the mixture quality) and optimum mixing time $\mathrm{k}_{\mathrm{opt}}$ (the increase of mixing capacity). If we compare the key component distribution at the optimum mixing time for the one time loading (Case 1) and the same for the loading as 8 sandwiches (Case 4) we can see a big difference. At one time loading the best mixture that can be obtained remains rather non-homogeneous, while it is close to the perfect one at loading as 8 sandwiches. It is also important that this mixture can be reached more than 10 times faster. Thus, the more layers we have in the mixer load, the better. Despite of the fact that this conclusion is more or less obvious, it gets the quantitative estimation on the basis of the proposed model of mixing.

However, the process of multilayer loading take more and more time with the growing number of layers, or sandwiches that obviously influences on the total capacity of mixing. Let us suppose that the loading time (measured in the number of time transition of duration $\Delta t$ ) is directly proportional to the number of sandwiches $\mathrm{J}$. In this case, the duration of the mixing cycle "loading plus mixing" $\mathrm{K}$ can be calculated as:

$$
\mathrm{K}=\mathrm{k}_{\text {mix }}+\beta \mathrm{J} \text {, }
$$

where $\mathrm{k}_{\text {mix }}$ is the mixing time proper, $\beta$ is the proportional coefficient.

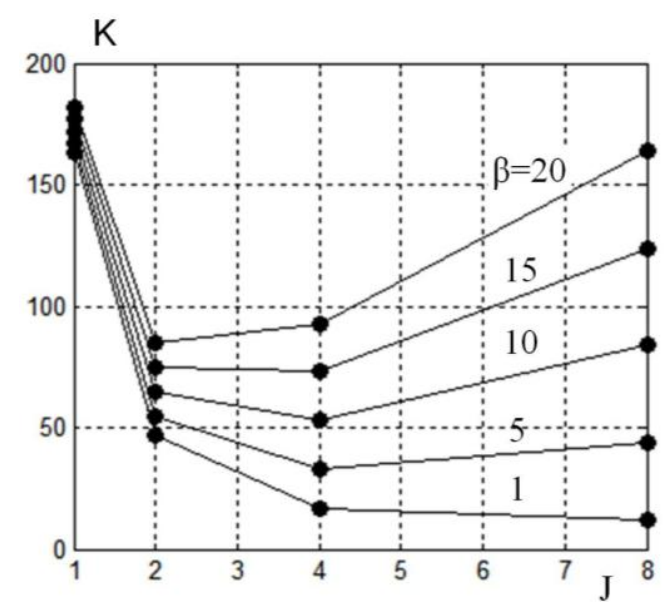

Fig. 2. Influence of the number of sandwiches on the total mixing time at different value of $\beta$

Рис. 2. Влияние количества сандвичей на общее время смешения при различном значении $\beta$

In order to compare the different cases of loading shown in Fig. 1, let us also suppose that the mixing homogeneity $\sigma_{\min }=0.0824$, which can be reached at one-time loading, meets the technological requirement, and the only objective of multilayer loading is to increase the mixing capacity. The required mixing times for different multilayer loading can be easily found for each case from the kinetic curves in Fig. 1.

Fig. 2 illustrates how the total mixing time $\mathrm{K}$ varies with the number of sandwiched at different value of $\beta$.

It can be seen from the graphs that at very fast loading $(\beta=1)$ the best case is to have 8 sandwiches while at slow loading $(\beta=20) 2$ sandwiches are preferable. The optimum number of sandwiches exists depending on $\beta$.

\section{EXPERIMENTAL}

The objective of this section is not to present the results of detailed experimental study of a mixer with multilayer loading but just to demonstrate an example that the multilayer loading can be realized in practice. One of possible technical solutions of multilayer loading is presented schematically in Fig. 3.

A movable cylindrical basket separated by vertical partitions into two sections proportionally to the volume of components to be mixed is inserted into the cylindrical mixing chamber of a vibration mixer. The basket has a perforated bottom but also can be without the bottom at all. The basket has the possibility to rotate around the vertical axis and to move up in the vertical direction. Actually, the partitions play the key role, and they can be adjusted to the vertical shaft even without the basket. The components are loaded into the sections formed by the partitions up to the identical level. After that the basket is brought in motion. It rotates and, at the same time, moves up leaving the components layer by layer on the bottom of the mixing chamber. After all the material lefts the basket, we get as many sandwiches as many turns the basket does during its motion to the upper point. Then the basket should be moved out, and the formed multilayer mixture should get a short time vibration agitation to finish mixing.

In order to check such loading process in practice, the experimental set-up was made. Its photograph is shown in Fig. 4a. The mixing chamber was imitated by the transparent glass, and the partitions were installed at the vertical shaft without basket. The shaft was driven by two independent electrical motors with regulated frequency of rotation placed on the frame. The fine ground salt and buckwheat in equal proportion were used as the test materials. 


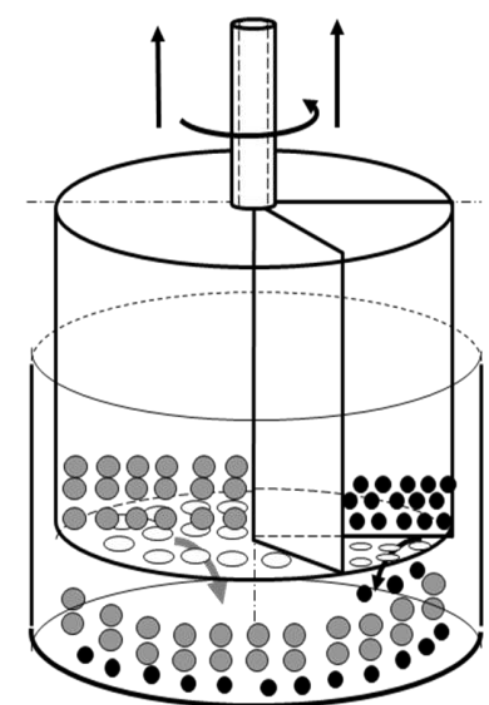

Fig.3. Schematic presentation of loading device for multilayer loading

Рис. 3. Схема загрузочного устройства при многослойной загрузке

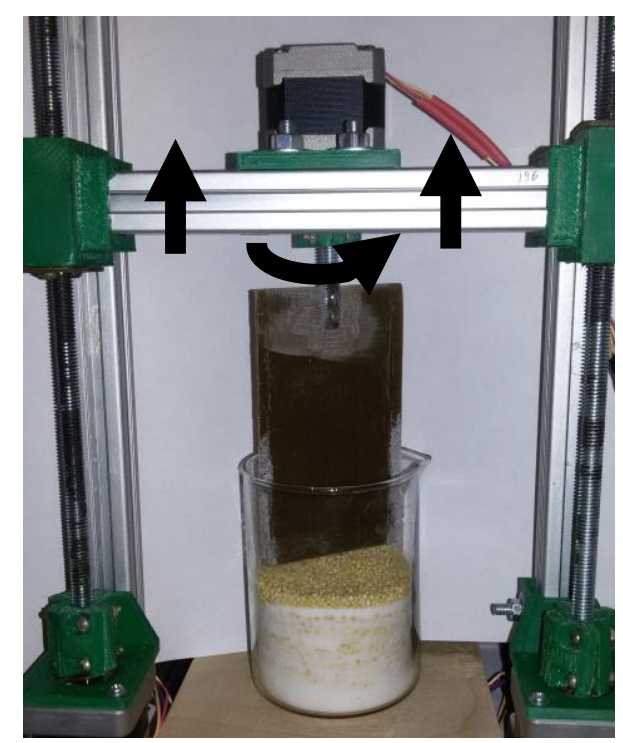

a

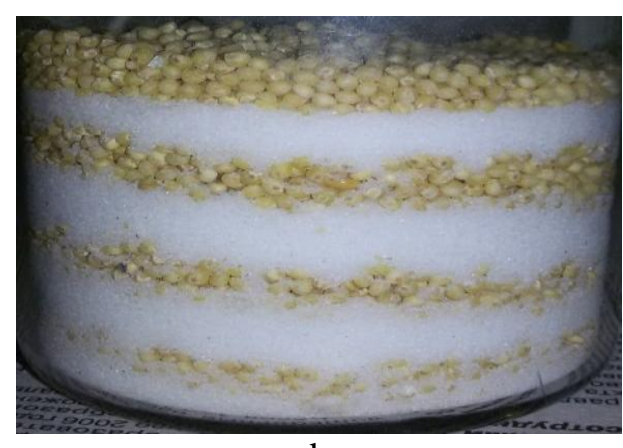

b

Fig. 4. The experimental set-up (a) and fragment of components distribution (b) at multilayer loading

Рис. 4. Экспериментальная установка (а) и фрагмент распределения компонентов при многослойной загрузке (b)
Fig. $4 \mathrm{~b}$ gives an example of the layers formation. It can be seen that the proposed device for multilayer loading runs the process rather well. After placing the mixing glass on a vibration table and applying a short time vibration action the mixture becomes very close to the homogeneous one (like for the case 3 or 4 in Fig. 1).

\section{CONCLUSIONS AND PERSPECTIVES}

It is shown that transition from one-time loading of dissimilar particulate solids in a batch vibration mixer to multilayer loading of them is a considerable reserve of improving the mixing quality and productivity. It is also shown that if the loading time and mixing time are taken into account together, the optimum number of layers exists that provide the maximum productivity under mixing quality being equal. The technical possibility to realize the multilayer loading is demonstrated experimentally that opens the ways to improve the design of vibration mixers. According to our viewpoint, the further development of the approach lies in transition to ternary and more components mixtures in modeling and to complete experimental validation of such process at a pilot scale mixer.

\section{ACKNOWLEDGEMENT}

This work is supported by the Russian Foundation for Basic Research (project 15-08-01684).

\section{REFERENCES}

1. Bridgwater J. Mixing of particles and powders: Where next? Particuology. 2010. V. 8. P. 563-567. DOI:10.1016/ j.partic.2010.07.001.

2. Bridgwater J.Mixing of powders and granular materials by mechanical means - A perspective. Particuology. 2012. V. 10. P. 397-427. DOI:10.1016/j.partic.2012.06.002.

3. Jha A.K., Gill J.S., Puri V.M. Percolation segregation in binary size mixtures of spherical and angular-shaped particles of different densities. Particulate Science and Technology. 2008. V. 26. P. 482-493. DOI:10.1080/ 02726350802367902.

4. Tang P., Puri V.M. Segregation quantification of twocomponent particulate mixtures: effect of particle size, density, shape, and surface texture. Particulate Science and Technology. 2007. V. 25. P. 571-588. DOI:10.1080/02726350701783977.

5. Puri V.M., Jha A.K. Percolation segregation of multi-size and multi-component particulate materials. Powder Technology. 2010. V. 197. P. 274-282. DOI:10.1016/j.powtec.2009.10.004.

6. Wang R.H., Fan L.T. Axial mixing of grains in a motionless Sulzer (Koch) mixer. Ind. Eng. Chem. Process Des. Dev. 1976. V. 15. P. 381-388. DOI:10.1021/i260059a005. 
7. Wang R.H., Fan L.T. Stochastic modeling of segregation in a motionless mixer. Chem. Eng. Sci. 1977. V. 32 P. 695-701. DOI:10.1016/0009-2509(77)80116-4.

8. Fan L.T., Lai R.S. Numerical and experimental simulation studies on the mixing of particulate solids and the synthesis of a mixing system. Computers and Chemical Engineering. 1978. V. 2. P. 19-32. DOI:10.1016/00981354(78)80003-9.

9. Berthiaux H., Mizonov V. Applications of Markov Chains in Particulate Process Engineering: A Review. Canad. J. Chem. Eng. 2004. V. 85. P. 1143-1168. DOI:10.1002/cjce.5450820602.
10. Berthiaux H., Mizonov V., Zhukov V. Application of the theory of Markov chains to model different processes in particle technology. Powder Technology. 2005. V. 157. P. 128-137. DOI:10.1016/j.powtec.2005.05.019.

11. Berthiaux H., Marikh K., Mizonov V., Ponomarev D., Barantzeva E. Modelling Continuous Powder Mixing by Means of the Theory of Markov Chains. Particulate Science and Technology. 2004. V. 22. P. 379-389. DOI:10.1080/02726350490516037.

12. Mizonov V., Berthiaux H., Gatumel C. Theoretical search for solutions to minimize negative influence of segregation in mixing of particulate solids. Particuology. 2016. V. 25. P. 36-41. DOI:10.1016/j.partic.2015.05.002. 